\title{
4 \\ Patterns of Aid for Trade
}

Given the programmes available and the requirements for accessing the funds, how much aid for trade have SVEs actually received? From what donors? What type of AfT? The objective of this section is to take stock of the scale and types of aid for trade to SVEs by extracting data mainly from the OECD/DAC database. The section will examine a number of issues, such as whether SVEs are receiving different amounts or types of AfT funds relative to other developing countries; what types of activities/ sectors this aid is funding; and the distribution of funds across SVEs and over time.

\subsection{Current and past flows by recipient}

AfT has been on the increase for the last few years, together with an increase in total official development assistance (ODA), although the share of AfT in total ODA has been decreasing steadily since the early 1990s (Figure 4.1). The relative significance of both aid for economic infrastructure and the productive sector in total aid has declined.

\section{Figure 4.1. Share of total aid for economic infrastructure and productive sector}

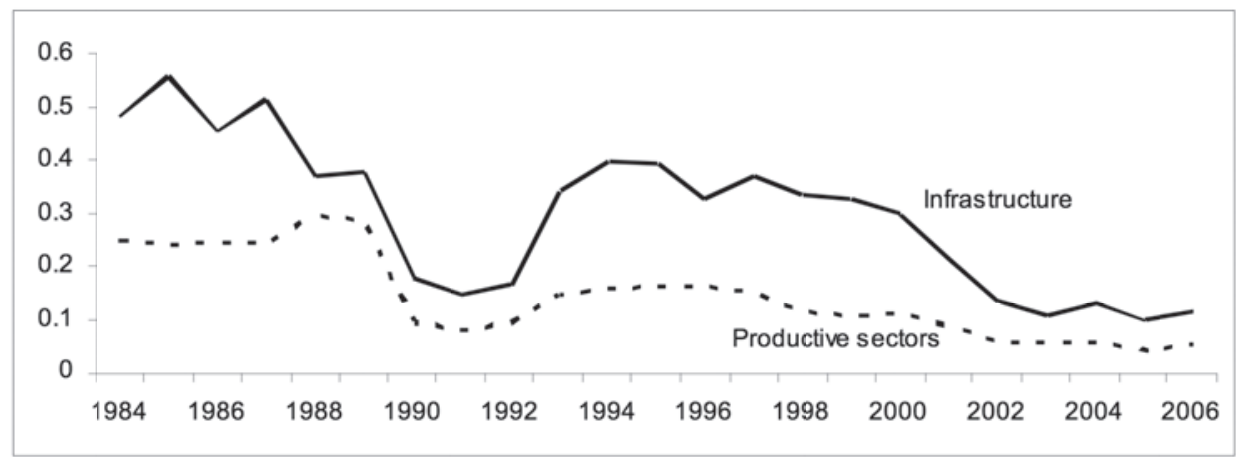

Source: OECD CRS disbursements

Table 4.1 shows the main recipients (in US\$ million) of AfT disbursements between 2002 and 2007 (although the data for 2007 are preliminary). We can identify two major types of AfT beneficiaries: large countries and countries in post-conflict situations. Most of the major ten recipients are large low-income countries, including China, India, Indonesia, Vietnam, Philippines and Egypt. In addition, large amounts of AfT (especially in the form of aid for economic infrastructure) have been given in recent years to Iraq and Afghanistan, which were not major recipients of aid before 
being occupied by US-led forces. The first sub-Saharan recipient, Ethiopia, is in the 11th position (not shown in the table), confirming a different (less trade-related) model of development assistance for sub-Saharan Africa compared to Asia (Calì, 2007). SVEs receive small absolute amounts of AfT, and the largest recipient of AfT is Papua New Guinea, which ranks 32nd among all countries. Others SVEs are lower in the ranking (below the 66th position). This clearly points to the relevance of size in AfT (as well as general aid) allocation. However, SVEs' share in AfT has been declining over the period 2002-2006, while in 2007 it bounced back, based on preliminary data.

Table 4.1. Main recipients of AfT (US\$ million)

\begin{tabular}{|c|c|c|c|c|c|c|c|c|}
\hline & 2002 & 2003 & 2004 & 2005 & 2006 & $2007^{a}$ & 2002-2007 & Rank \\
\hline Iraq & 0 & 474.3 & $1,304.7$ & $2,630.2$ & $2,761.3$ & $1,587.1$ & $8,757.7$ & 1 \\
\hline China & 529.7 & 563.2 & 839.3 & 899.8 & 641.3 & 335.5 & $3,808.8$ & 2 \\
\hline India & 496.7 & 434.6 & 611.3 & 586.8 & 601.8 & 195.7 & $2,926.8$ & 3 \\
\hline Afghanistan & 19.2 & 78.8 & 388.4 & 741.3 & 676.3 & 754.7 & $2,658.8$ & 4 \\
\hline Egypt & 449.1 & 413.7 & 482.3 & 561.1 & 435.8 & 270.7 & $2,612.6$ & 5 \\
\hline Vietnam & 122.4 & 276.0 & 393.8 & 565 & 565.9 & 196.3 & $2,119.4$ & 6 \\
\hline Thailand & 225.3 & 183.7 & 571.9 & 513.8 & 244.7 & 41.5 & $1,781.0$ & 7 \\
\hline Indonesia & 91.0 & 191.5 & 213.0 & 280.7 & 632.3 & 183.4 & $1,591.9$ & 8 \\
\hline Philippines & 96.4 & 187.4 & 171.6 & 255.2 & 305.3 & 148.5 & $1,164.3$ & 9 \\
\hline Morocco & 34.6 & 75.8 & 110.4 & 262.1 & 313.9 & 327.2 & $1,123.9$ & 10 \\
\hline \multicolumn{9}{|l|}{ SVEs } \\
\hline Papua New Guinea & 60.7 & 62.2 & 70.5 & 69 & 45.1 & 97.9 & 405.3 & 32 \\
\hline Cape Verde & 5.7 & 19.6 & 13.9 & 43 & 33.1 & 29.7 & 145.0 & 67 \\
\hline Gabon & 22.2 & 18.9 & 27.8 & 28.5 & 14.9 & 32.1 & 144.3 & 68 \\
\hline Jamaica & 14.3 & 11.1 & 11.4 & 29.8 & 22.3 & 37.3 & 126.1 & 74 \\
\hline Swaziland & 3.0 & 5.1 & 6.7 & 25.3 & 14.4 & 2.4 & 56.9 & 95 \\
\hline Solomon Islands & 3.0 & 4.6 & 5.8 & 17.1 & 18.2 & 1.0 & 49.6 & 99 \\
\hline Dominica & 11.0 & 2.1 & 15.8 & 2.6 & 5.6 & 10.2 & 47.2 & 101 \\
\hline Lesotho & 12.1 & 18.2 & 8.1 & 3.2 & 4.1 & 1.2 & 46.9 & 102 \\
\hline Botswana & 1.1 & 1.7 & 2.9 & 16.2 & 9.8 & 12.5 & 44.2 & 104 \\
\hline Gambia, The & 9.6 & 10.5 & 7.0 & 4.7 & 4.0 & 7.9 & 43.6 & 105 \\
\hline Kiribati & 8.1 & 6.0 & 4.1 & 13.0 & 9.6 & 0.9 & 41.8 & 110 \\
\hline Suriname & 3.3 & 2.3 & 2.4 & 5.7 & 4.1 & 23.9 & 41.8 & 109 \\
\hline Fiji Islands & 0.3 & 5.0 & 10.4 & 11.3 & 9.0 & 3.7 & 39.8 & 112 \\
\hline Samoa & 11.0 & 10.2 & 4.8 & 3.9 & 6.4 & 0.7 & 37.0 & 113 \\
\hline Mauritius & 3.0 & 6.9 & 7.9 & 2.2 & 1.7 & 12.6 & 34.4 & 117 \\
\hline Vanuatu & 3.3 & 3.0 & 4.8 & 5.6 & 4.9 & 10.0 & 31.5 & 118 \\
\hline Guyana & 5.2 & 4.0 & 3.6 & 5.6 & 3.8 & 9.3 & 31.3 & 119 \\
\hline São Tomé \& Principe & 4.2 & 3.2 & 5.4 & 7.5 & 5.1 & 5.8 & 31.2 & 120 \\
\hline
\end{tabular}

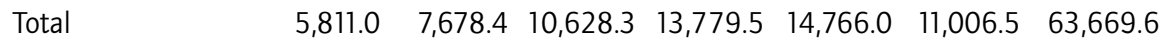

\begin{tabular}{lrrrrrrr}
\hline Total SVEs & 220.0 & 228.2 & 258.7 & 334.1 & 259.8 & 347.0 & $1,647.9$ \\
\hline Total others & $5,591.0$ & $7,450.2$ & $10,369.6$ & $13,445.3$ & $14,506.1$ & $10,659.4$ & $62,021.7$ \\
\hline
\end{tabular}

aPreliminary: countries in ascending rank in terms of total 2002-2007 value.

Source: OECD/DAC CRS database 
In order to account for the importance of size in AfT allocation, we compute the values of AfT per capita received by beneficiaries. Table 4.2 presents the results. In fact this computation drastically changes the relative rankings of the major recipients, with small countries receiving proportionately more AfT. The main recipients in terms of per capita income are mainly small and very small islands in the Pacific and the Caribbean. Of the largest 50 recipients of AfT per capita, only Iraq and Afghanistan have a population of more than 10 million. Given this trend, it is not surprising that SVEs receive relatively higher levels of AfT per capita. In fact four of the major ten recipients and 12 of the major 20 are SVEs. On average between 2002 and 2007 SVEs received an amount of AfT per capita five times larger than the rest of the developing countries. However, as noted above, this gap narrowed in the period up to 2006.

Table 4.2. Main recipients of AfT (US\$ per capita)

\begin{tabular}{|c|c|c|c|c|c|c|c|c|}
\hline & 2002 & 2003 & 2004 & 2005 & 2006 & $2007^{a}$ & 2002-2007 & Rank \\
\hline Montserrat & 1193 & 1636 & 1452 & 986 & 1576 & 514 & 1226 & 1 \\
\hline St Helena & 50 & 116 & 395 & 390 & 1177 & 1114 & 540 & 2 \\
\hline Wallis \& Futuna & 234 & 347 & 2041 & 133 & 0 & 191 & 491 & 3 \\
\hline Palau & 613 & 394 & 110 & 331 & 319 & 16 & 297 & 4 \\
\hline Nauru & 1 & 16 & 20 & 154 & 499 & 518 & 201 & 5 \\
\hline Tuvalu & 325 & 86 & 63 & 79 & 616 & 0 & 195 & 6 \\
\hline Mayotte & 138 & 122 & 361 & 2 & 1 & 179 & 134 & 7 \\
\hline Dominica & 155 & 29 & 221 & 37 & 77 & 141 & 110 & 8 \\
\hline Anguilla & 31 & 127 & 117 & 30 & 331 & 0 & 106 & 9 \\
\hline Kiribati & 86 & 63 & 42 & 131 & 96 & 9 & 71 & 10 \\
\hline Iraq & 0 & 19 & 51 & 101 & 103 & 58 & 55 & 12 \\
\hline Cape Verde & 12 & 41 & 28 & 85 & 64 & 56 & 48 & 13 \\
\hline Antigua \& Barbuda & 106 & 34 & 15 & 66 & 23 & 0 & 41 & 14 \\
\hline St Kitts \& Nevis & 133 & 0 & 7 & 14 & 88 & 0 & 40 & 15 \\
\hline Tonga & 28 & 33 & 34 & 28 & 36 & 53 & 35 & 16 \\
\hline São Tomé \& Principe & 29 & 22 & 36 & 49 & 33 & 37 & 34 & 17 \\
\hline Samoa & 61 & 56 & 26 & 21 & 34 & 4 & 34 & 18 \\
\hline St Lucia & 47 & 19 & 20 & 37 & 19 & 28 & 28 & 20 \\
\hline Grenada & 12 & 70 & 73 & 4 & 5 & 4 & 28 & 21 \\
\hline St Vincent \& Grenadines & 50 & 8 & 45 & 25 & 18 & 58 & 26 & 24 \\
\hline Seychelles & 10 & 24 & 15 & 29 & 68 & 7 & 26 & 25 \\
\hline Vanuatu & 16 & 15 & 23 & 26 & 22 & 44 & 24 & 26 \\
\hline Gabon & 18 & 15 & 22 & 22 & 11 & 24 & 19 & 29 \\
\hline Solomon Islands & 7 & 10 & 13 & 36 & 38 & 2 & 18 & 30 \\
\hline Suriname & 8 & 5 & 5 & 13 & 9 & 52 & 15 & 33 \\
\hline Average SVEs & 8.15 & 8.33 & 9.30 & 11.84 & 9.08 & 11.97 & 9.78 & \\
\hline Average others & 1.10 & 1.45 & 1.99 & 2.54 & 2.71 & 1.96 & 1.96 & \\
\hline Total average & 1.14 & 1.49 & 2.03 & 2.59 & 2.74 & 2.02 & 2.00 & \\
\hline
\end{tabular}

apreliminary: countries in ascending rank in terms of total 2002-2007 value.

Source: OECD/DAC CRS database 


\subsection{Current and past flows by donor}

Figure 4.2 shows the value of AfT disbursements by donor (in log scale) and the value going specifically to SVEs. In 2002-2007 the USA was the largest donor, mainly due to the assistance provided in Iraq and Afghanistan for reconstruction. Taking away that assistance, Japan becomes the largest provider of AfT (2007 data for Japan has not yet been collected). The EC is the third largest contributor, with member states Germany, France, the Netherlands, UK, Spain and Sweden being important donors. The low share of multilateral donors is due to the fact that they mainly manage funds provided by bilateral donors, and only a small part of their activities is funded directly by them. Interestingly, the picture changes significantly when we consider the traderelated assistance provided to SVEs. The EC has been the largest provider of AfT to SVEs in the 2002-2007 period, followed by Australia and Japan. The USA is a fairly unimportant AfT donor for SVEs, preceded also by France and Portugal. As is shown below, some countries prioritise assistance to certain SVEs, such as Australia, which funds activities in a number of SVEs in the Pacific region, and the EC, which assists small states in the Caribbean and the Pacific through programmes aimed at diversifying their economies.

\section{Figure 4.2. AfT disbursements by donor, 2002-2007 (log of US\$ million)}

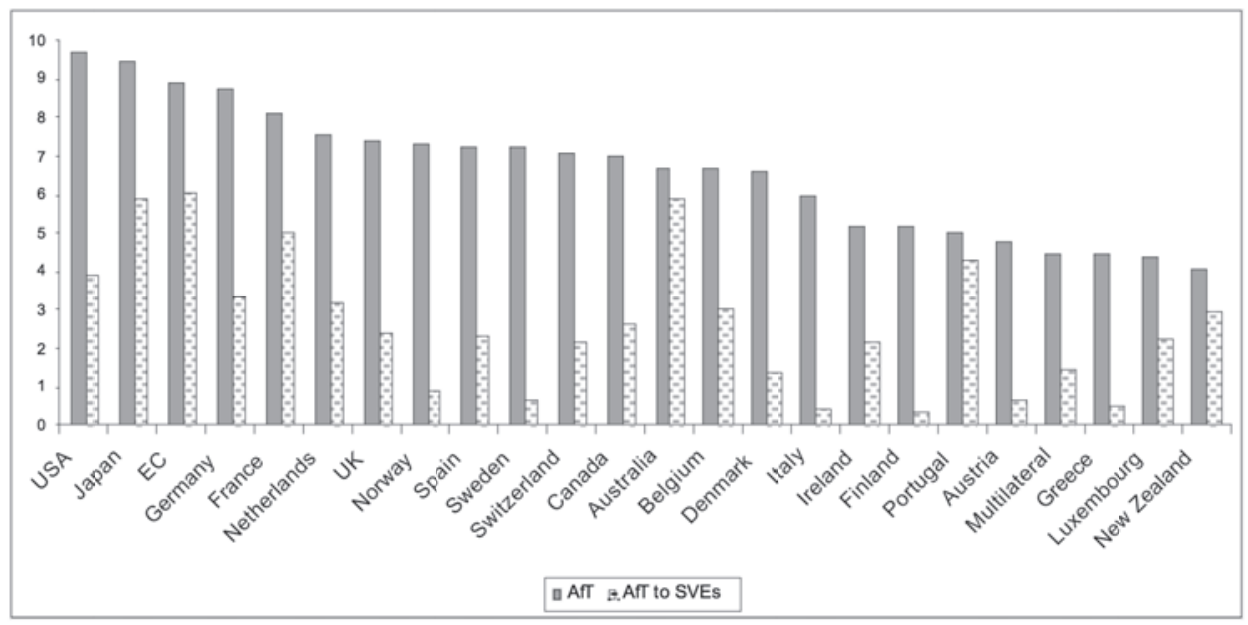

Source: OECD/DAC CRS

In order to understand the relative importance that donors attach to AfT, we estimate the extent to which countries specialise in this type of assistance by constructing a simple index of specialisation for all major aid donors (Calì, 2007). The index is the ratio of the share of a country in total aid for trade and the share of the country in total ODA: 


$$
S_{i}=\frac{A f T_{i} / \sum_{j=1}^{n} A f T_{j}}{A_{i} /\left(\sum_{j=1}^{n} A_{j}\right)}
$$

where $\operatorname{AfT}_{i}$ and $A_{i}$ are aid for trade (in US\$) and total ODA for country $i$ respectively, and $n$ is the total number of donors. ${ }^{10} \mathrm{~A}$ value of the index greater than 1 indicates that the donor is spending proportionally more on aid for trade. Table 4.3 shows that Japan and the EC are the donors with the highest specialisation in AfT over the entire period 2002-2007, although the intensity of this specialisation has declined somewhat. The value for the EC is mainly driven by expenditure on trade policy and regulation and trade development, while Japan's value is the result of the focus on infrastructure in its development assistance strategy. Among the major donors, the USA has had an index greater than 1 only since 2004, because of the shock in its aid pattern related to the reconstruction in Iraq and Afghanistan. All the other main bilateral donors except for Germany and Norway - have been spending little on trade-related assistance relative to general ODA, with Italy, France and UK at the bottom of the list. The multilateral donors tended to have a consistent specialisation in AfT throughout the period.

Table 4.3. Index of aid for trade specialisation (by main donor and year)

\begin{tabular}{lllllllc}
\hline & $\mathbf{2 0 0 2}$ & $\mathbf{2 0 0 3}$ & $\mathbf{2 0 0 4}$ & $\mathbf{2 0 0 5}$ & $\mathbf{2 0 0 6}$ & $\mathbf{2 0 0 7}^{\mathrm{a}}$ & $\mathbf{2 0 0 2 - 0 7}$ \\
\hline Japan & 1.88 & 1.99 & 1.52 & 1.65 & 1.68 & & 1.72 \\
EC & 2.59 & 2.41 & 1.82 & 1.45 & 1.23 & 1.71 & 1.59 \\
Switzerland & 1.44 & 1.75 & 1.22 & 1.08 & 1.0 & 1.11 & 1.22 \\
Multilateral & 1.56 & 1.42 & 1.05 & 1.12 & 0.97 & 1.34 & 1.17 \\
Germany & 1.42 & 1.14 & 1.19 & 0.79 & 1.08 & 1.35 & 1.12 \\
USA & 0.67 & 0.74 & 1.07 & 1.21 & 1.29 & 1.26 & 1.09 \\
Norway & 1.08 & 0.83 & 1.06 & 0.98 & 0.88 & 1.41 & 1.06 \\
Canada & 1.64 & 1.41 & 0.71 & 0.71 & 0.84 & 1.1 & 0.95 \\
Sweden & 1.02 & 0.92 & 0.61 & 0.97 & 0.67 & 0.95 & 0.83 \\
Australia & 1.19 & 0.97 & 0.78 & 0.7 & 0.52 & 0.74 & 0.74 \\
Netherlands & 0.53 & 0.61 & 0.5 & 0.63 & 0.74 & 0.69 & 0.63 \\
New Zealand & 0.27 & 0.78 & 0.53 & 0.4 & 0.71 & & 0.56 \\
France & 0.6 & 0.35 & 0.45 & 0.4 & 0.41 & 1.03 & 0.51 \\
UK & 0.9 & 0.99 & 0.75 & 0.43 & 0.4 & & 0.4 \\
Italy & 0.06 & 0.25 & 0.70 & 0.54 & 0.39 & 0.0 & 0.38 \\
\hline
\end{tabular}

aPreliminary.

Note: The index is obtained by dividing the share of a country in total aid for trade over the share of the country in total ODA. An index greater than 1 means relative specialisation in AfT.

Source: Authors' calculations from OECD DAC (2009) 


\subsection{Aid for trade to SVEs}

Figure 4.3 shows to what extent donors are focusing on SVEs in their AfT spending. Portugal, Australia and New Zealand devote a large share of their AfT to SVEs (around 40 per cent in 2007). In the case of the Oceanic countries, this is driven by the special attention granted to their Pacific neighbours, which are mainly small island developing countries, such as Papua New Guinea, Fiji Islands, Samoa and Tonga. In the case of Portugal, the result is mainly due to its assistance to its former colony of Cape Verde. Among the major donors, the EC provides the largest share of its AfT to SVEs (over 6 per cent of the total in 2007 and 5.7 per cent on average over the period).

Figure 4.3. Share of AfT disbursement allocated to SVEs, by donor and year

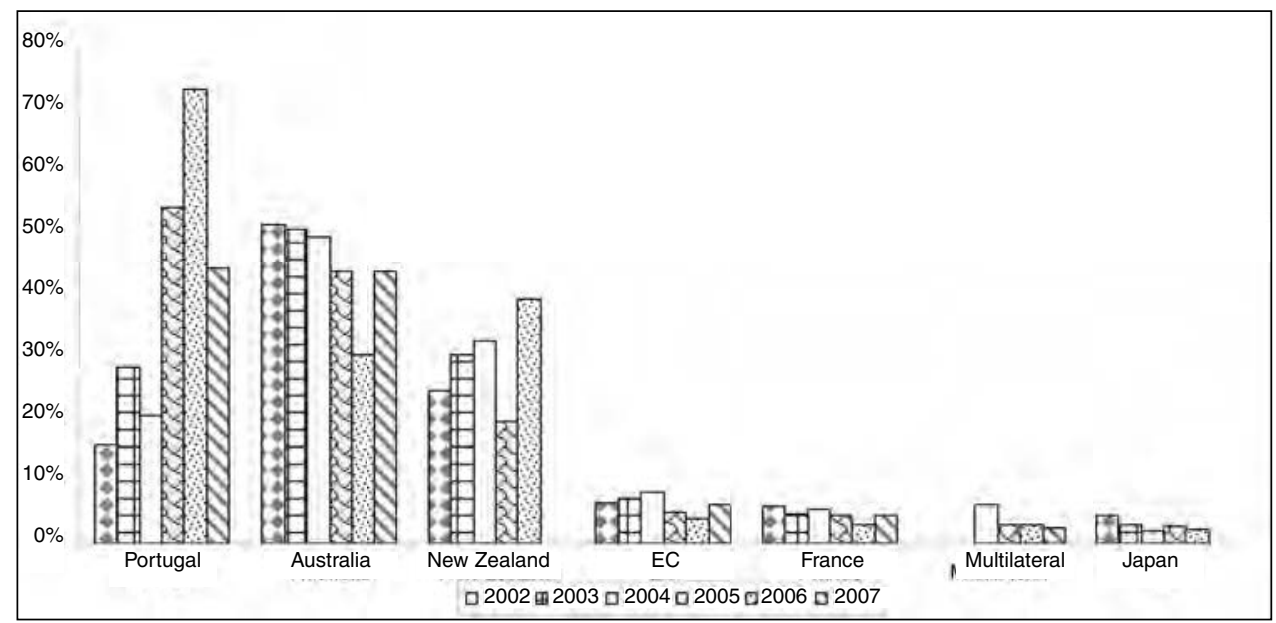

Source: Authors' calculation from OECD DAC (2009)

The relative focus of donors on SVEs only tells part of the story about the largest providers of AfT to SVEs. Figure 4.4 shows that the EC has been consistently the largest donor in the period 2002-2007, with more than US\$150 million disbursed in 2007, almost double the amount for 2006. Australia and Japan are the other main AfT donors to SVEs, with the former more than doubling its assistance in 2007.

The above analysis has provided some rationale for external assistance to SVEs in the form of AfT. Thus it is worth asking whether SVEs are receiving relatively more or less aid as AfT. According to the specialisation index in Table 4.4 (calculated as for the donors above), SVEs received roughly the same proportion of AfT as of ODA in 2002-2007 period. However, this index has varied over time. While at the beginning of the period SVEs were receiving disproportionately more AfT given their share in total ODA (their specialisation index was higher than that of any income groups in 2002), this was reversed in the following years (and in 2004 SVEs' specialisation index was 


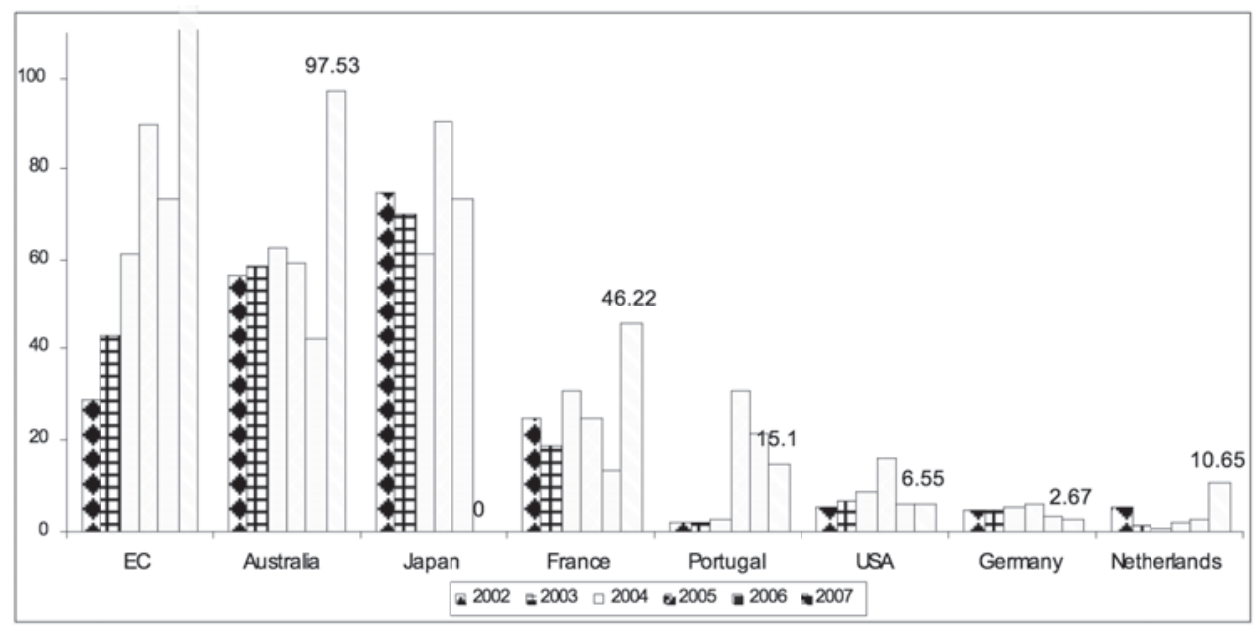

Source: Authors' calculation from OECD DAC (2009)

lower than that of any income group). These large swings suggest that there may not be a long-term strategy in terms of AfT allocation across countries, and to SVEs in particular. This is also influenced by shocks that may have a large impact on aid (including AfT) allocation decisions, such as wars, natural calamities and changes in market access.

Table 4.4. Destination of AfT by income group, shares in total and specialisation index

\begin{tabular}{lrrrrrrc}
\hline & 2002 & $\mathbf{2 0 0 3}$ & $\mathbf{2 0 0 4}$ & $\mathbf{2 0 0 5}$ & $\mathbf{2 0 0 6}$ & $\mathbf{2 0 0 7}^{\mathrm{a}}$ & $\mathbf{2 0 0 2 - 2 0 0 7}$ \\
\hline LDCs (share) & 22.45 & 24.27 & 20.75 & 20.43 & 19.13 & 28.94 & 22.3 \\
LDCs (index) & 0.89 & 0.77 & 0.7 & 0.94 & 0.84 & 1.07 & 0.86 \\
\hline Other low income (share) & 20.69 & 16.67 & 15.6 & 13.81 & 13.1 & 12.05 & 14.61 \\
Other low income (index) & 1.15 & 1.06 & 1.06 & 0.85 & 0.56 & 0.94 & 0.86 \\
\hline Low-middle income (share) & 39.67 & 41.11 & 48.25 & 50.98 & 48.35 & 37.67 & 45.39 \\
Low-middle income (index) & 1.17 & 1.32 & 1.54 & 1.18 & 1.61 & 1.29 & 1.35 \\
\hline Upper-middle income (share) & 3.72 & 4.27 & 3.91 & 3.45 & 4.43 & 2.73 & 3.75 \\
Upper-middle income (index) & 0.84 & 1.06 & 0.96 & 1.07 & 1.07 & 0.6 & 0.94 \\
\hline SVEs (share) & 4.15 & 3.26 & 2.55 & 2.51 & 1.82 & 3.26 & 2.73 \\
SVEs (index) & 1.44 & 1.18 & 0.68 & 1.14 & 0.92 & 1.22 & 1.04 \\
\hline Total AfT (US\$ million) & 5,810 & 7,678 & 10,628 & 13,779 & 14,765 & 11,006 & 63,669 \\
\hline
\end{tabular}

aPreliminary

Note: The index is obtained by dividing the share of the group in total aid for trade over the share of the group in total ODA. An index greater than 1 means relative specialisation in aid for trade.

Source: Authors' calculation from OECD DAC (2009) 
Table 4.5 complements these findings by calculating the regional indices of relative specialisation in AfT. North Africa and the Far East appear to be the regions with the highest level of trade-related aid relative to the total aid they receive, while subSaharan Africa, central America and south America have the lowest rankings on the index. The influence of the EC's and Japan's (trade-oriented) mode of development assistance may account for the large weight of AfT in those two regions. On the other hand, a more socially-related mode of spending, for instance on health and education, seems to have prevailed in the other regions, particularly in sub-Saharan Africa and the Americas. Investment in infrastructure in the context of Iraq and Afghanistan reconstruction and in the post-tsunami period account for most of the increase in the specialisation index in the Middle East (Iraq) and south and central Asia.

Table 4.5. Destination of AfT by region, shares in total and specialisation index

\begin{tabular}{|c|c|c|c|c|c|c|c|}
\hline & 2002 & 2003 & 2004 & 2005 & 2006 & $2007^{a}$ & 2002-2007 \\
\hline North Africa (share) & 9.3 & 7.5 & 6.7 & 7.6 & 7.0 & 7.7 & 7.5 \\
\hline North Africa (index) & 1.7 & 2.1 & 1.6 & 2.3 & 2.2 & 1.8 & 1.9 \\
\hline Sub-Saharan Africa (share) & 24.2 & 23.5 & 19.1 & 16.9 & 17.0 & 27.9 & 20.7 \\
\hline Sub-Saharan Africa (index) & 0.8 & 0.7 & 0.6 & 0.6 & 0.5 & 0.9 & 0.6 \\
\hline Central America (share) & 4.1 & 3.3 & 2.9 & 2.7 & 2.8 & 0.9 & 2.7 \\
\hline Central America (index) & 1.1 & 0.9 & 0.6 & 0.8 & 0.8 & 0.3 & 0.7 \\
\hline South America (share) & 3.7 & 4.2 & 5.7 & 3.3 & 3.2 & 3.4 & 3.8 \\
\hline South America (index) & 0.7 & 0.9 & 1.1 & 1.1 & 0.9 & 1.1 & 1.0 \\
\hline Far East Asia (share) & 22.5 & 21.2 & 22.4 & 20.0 & 18.5 & 9.7 & 18.7 \\
\hline Far East Asia (index) & 1.7 & 1.6 & 1.8 & 1.9 & 1.9 & 1.5 & 1.8 \\
\hline South and central Asia (share) & 18.2 & 17.1 & 16.6 & 15.4 & 14.1 & 15.0 & 15.7 \\
\hline South and central Asia (index) & 1.2 & 1.3 & 1.6 & 1.7 & 1.4 & 1.4 & 1.4 \\
\hline Middle East (share) & 1.1 & 7.1 & 12.9 & 20.4 & 20.0 & 16.3 & 15.0 \\
\hline Middle East (index) & 0.4 & 1.0 & 1.5 & 0.9 & 1.7 & 1.2 & 1.2 \\
\hline Eastern Europe (share) & 5.8 & 4.7 & 3.6 & 4.4 & 6.8 & 5.9 & 5.2 \\
\hline Eastern Europe (index) & 0.7 & 1.1 & 1.1 & 1.0 & 1.3 & 1.3 & 1.1 \\
\hline Oceania (share) & 2.1 & 1.8 & 1.6 & 1.2 & 1.0 & 1.3 & 1.4 \\
\hline Oceania (index) & 1.4 & 1.3 & 1.1 & 1.2 & 0.9 & 1.0 & 1.1 \\
\hline
\end{tabular}

aPreliminary

Note: The index is obtained by dividing the share of the group in total aid for trade over the share of the group in total ODA. An index greater than 1 means relative specialisation in aid for trade.

Source: Authors' calculation on OECD DAC (2009) 
Table 4.6. AfT by category (disbursements in US\$ per capita)

\begin{tabular}{llcccccc}
\hline & & $\mathbf{2 0 0 2}$ & $\mathbf{2 0 0 3}$ & $\mathbf{2 0 0 4}$ & $\mathbf{2 0 0 5}$ & $\mathbf{2 0 0 6}$ & $\mathbf{2 0 0 7 ^ { \mathrm { a } }}$ \\
\hline Economic infrastructure & SVE & 4.8 & 4.7 & 5.5 & 7.2 & 5.2 & 6.6 \\
& Non-SVE & 0.7 & 0.8 & 1.3 & 1.7 & 1.9 & 1.2 \\
& Ratio & 7.1 & 5.7 & 4.3 & 4.2 & 2.8 & 5.7 \\
\hline Productive sectors & SVE & 3.2 & 3.6 & 3.7 & 4.3 & 3.6 & 5.2 \\
& Non-SVE & 0.3 & 0.5 & 0.6 & 0.8 & 0.8 & 0.7 \\
& Ratio & 9.4 & 6.6 & 5.8 & 5.7 & 4.7 & 7.9 \\
\hline TPR & SVE & 0.1 & 0.1 & 0.1 & 0.3 & 0.2 & 0.2 \\
& Non-SVE & 0.1 & 0.1 & 0.1 & 0.1 & 0.1 & 0.1 \\
& Ratio & 1.2 & 0.6 & 1.3 & 3.6 & 2.9 & 1.3 \\
\hline Total AfT & SVE & 8.2 & 8.3 & 9.3 & 11.8 & 9.1 & 12.0 \\
& Non-SVE & 1.1 & 1.5 & 2.0 & 2.5 & 2.7 & 1.9 \\
& Ratio & 7.4 & 5.7 & 4.7 & 4.7 & 3.4 & 6.2 \\
\hline Total aid & SVE & 48.7 & 62.5 & 92.3 & 79.0 & 66.1 & 75.3 \\
& Non-SVE & 8.7 & 11.8 & 12.7 & 18.8 & 17.5 & 14.7 \\
& Ratio & 5.6 & 5.3 & 7.3 & 4.2 & 3.8 & 5.1 \\
\hline
\end{tabular}

aPreliminary

Source: Authors' calculation on OECD DAC (2009)

\subsection{Types of aid for trade provided to SVEs}

In order to identify what type of AfT is directed to SVEs, we divide it into three main categories (as in the OECD/DAC database): aid to economic infrastructure; aid to productive sectors; and aid for trade policy and regulation. The majority of the AfT funds accrue to economic infrastructure, as is the case for other developing countries. In terms of per capita aid, the ratio between SVEs and non-SVEs for the economic infrastructure category is similar to that of total ODA, while the same ratio is higher for aid to the productive sector, suggesting that AfT is relatively more targeted to this type of assistance. The opposite is true for trade policy and regulation, for which the ratio (although usually higher than 1 ) is much lower than for the other categories. A relatively important category of AfT for SVEs, that for trade-related adjustment, was not recorded at the time when this study was being prepared, suggesting that donors have not yet started to provide it.

In sum, the analysis suggests that small countries, and thus SVEs, receive higher per capita amounts of AfT - just as for general aid. However, AfT to SVEs declined somewhat in recent years until 2006, but seems to have bounced back in 2007. Whether this trend is just a temporary spike or the beginning of a new rising trend for SVEs is open to question. The previous sections have provided some arguments that in the context of increasing integration of the world economy small states may be in particular need of AfT. This assistance is provided mainly by a few large donors, including the EC, Australia and Japan, and to a lesser extent France, Portugal, the USA and New Zealand. 